\title{
PROSPECTS FOR ORGANIZATION OF RURAL TOURISM IN THE CHECHEN REPUBLIC
}

\author{
(C) Elena B. Ivushkina, Elena V. Dashkova
}

\author{
Chechen State University, Grozny, Chechen Republic, Russian Federation \\ science-almanac@mail.ru
}

In Russia, there are prospects for the development of various types of tourism. Historically, Russia has long been an agricultural country and large territories belong to rural settlements. Therefore, one of the priority types of tourism in our country is rural tourism. The interconnection of structural elements in the development of rural tourism is presented. In the Chechen Republic, there is some experience in the development of tourism in small towns since the Soviet era. For example, a tourist base in the village of Benoy in the Vedensky district functioned successfully. The base was of All-Union significance and up to three thousand tourists passed through it in a season. The modern socio-economic development of the Chechen Republic is aimed at the revival of the tourism industry. In the Chechen Republic, $65.26 \%$ of the population are rural residents. They are well aware of the way of rural life, traditions, customs, and features of rural life. The basis of rural tourism is the stay of tourists in the countryside, where the rural family takes care of the accommodation, food and service of the tourists. Organization of rural tourism may become a priority for the Chechen Republic

Key words: culture, Black Sea region, Turkey, Turkic languages, West European borrowings.

\section{[Е.Б. Ивушкина, Е.В. Дашкова Перспективы организации сельского туризма в Чеченской респуб- лике]}

В России существуют перспективы для развития различных видов туризма. Исторически сложилось так, что Россия на протяжении долгого времени была аграрной страной и большие территории относятся к сельским поселениям. Поэтому одним из приоритетных видов туризма в нашей стране является сельский туризм. Представлена взаимосвязь структурных элементов в развитии сельского туризма. В Чеченской Республике имеется определённый опыт развития туризма в малых населённых пунктах ещё с советских времён. К примеру, успешно функционировала туристская база в селении Беной в Веденском районе. База имела Всесоюзное значение и через неё в сезон проходило до трёх тысяч туристов. Современное социально-экономическое развитие Чеченской республики направлено на возрождение туриндустрии. В Чеченской Республике 65,26\% населения является сельскими жителями. Им хорошо известен уклад сельской жизни, традиции, обычаи, особенности сельского быта. Основа сельского туризма состоит в пребывании туристов в сельской местности, где проживание, питание и обслуживание туристов берёт на себя сельская семья. Организация сельского туризма может стать приоритетной для Чеченской Республики.

Ключевые слова: Северный Кавказ, туриндустрия, туризм, сельский туризм.

Elena B. Ivushkina - Ph.D. (Advanced Doctorate) in Philosophy, Professor, Chechen State University, Grozny, Chechen Republic, Russian Federation.

Elena V. Dashkova - Ph.D. in Philosophy, Associate Professor, Chechen State University, Grozny, Chechen Republic, Russian Federation.

Ивушкина Елена Борисовна - доктор фрилософрских наук, профрессор, Чеченский государственный университет, г. Грозный, Российская Федерация.

Дашкова Елена Валерьевна - кандидат философрских наук, доцент, Чеченский государственный университет, г. Грозный, Российская Федерация.

The Chechen Republic has unique tourist and recreational opportunities that must be included in the general system of the North Caucasus tourist cluster: unique nature, national traditions and customs, religious shrines, national cuisine, traditional agriculture.

The formation of rural tourism in this region may be a direction that contributes to the protection and development of cultural and historical heritage, attracting people to actively 
participate in solving their own economic problems, and promoting the employment of the local population. This is a real way of social development of depressed rural areas, which will help stop rural degradation, outflow of the population due to lack of work. To solve these problems through the development of rural tourism, it is necessary:

- to create rural tourism infrastructure;

- to provide state support to entrepreneurs in the field of rural tourism;

- to develop general documents regulating the development of rural tourism;

- to provide training for rural tourism [1,15]

The countryside has a powerful natural, demographic, economic and historical-cultural potential, which, if used more fully, rationally and efficiently, can ensure sustainable diversified development, full employment, a high level and quality of life for the rural population.

The population of the Chechen Republic is mainly rural (922100 people) and accounts for $63 \%$ (2019) of the total population of the region [4].

The development of rural areas must be considered as a complex. Rural tourism is an element of these activities. Its development will contribute to the economic well-being of rural residents, to popularize the Chechen culture with its ethnographic features.

Recreation areas are already appearing in rural zones of the Chechen Republic, which are very interesting for tourists and guests of the republic. One of them, the national ethnographic open-air museum "Shira-k1otar." He literally takes the visitor to the past when the Vainakhs lived in small but cozy and comfortable houses, with narrow but familiar streets and fences knitted from poles.

Another such area is the Dondi Yurt Museum in the city of Urus-Martan. It was opened by a local resident Adam Satuev. The museum is located on the western outskirts of the city, in a small area of about 20-30 acres. On the territory of the museum, Adam built a three-story tower and collected old exhibits for the museum.

The formation of rural tourism in the Chechen Republic will help revive the interest of rural residents in running their own farms.

The effective use of recreational resources in rural areas and the formation of rural tourism are more dependent on natural conditions and the number of natural and cultural heritage objects [3; 4].

There are main factors that influence the development of various types of tourism, including rural tourism: transport accessibility; high-quality water areas comfortable for use; mineral water sources, therapeutic mud and other balneological resources; aesthetics of natural landscapes; environmental ecology; natural and cultural heritage sites; climatic conditions.

Almost all regions of the Chechen Republic have the necessary resources for the development of rural tourism. Rural tourism is closely intertwined with ecological tourism, from which both benefit. A variety of nature with mountain landscapes and steppes, on which villages with their territories are located with fields, gardens, vineyards, pastures. Additional objects of ecological and cultural-educational purpose can be natural monuments, historical places of worship, monuments of architecture and archeology, which are located in these territories.

Rural areas, as a rule, tourists visit in the summer. This period of the year is replete with offers to its guests, different from urban living conditions. Among them: the use of vegetables, berries, herbs directly from the garden; long walks in the fresh air; the ability to drink unboiled water directly from natural sources; swimming in natural reservoirs; land works; cattle care; fresh village products; the opportunity to relax with your pets; participation in public holidays and entertainment. The autumn period offers harvesting, preparing pickles, berries. Rural tourism is becoming one of the sought-after types of recreation on a global scale.

The business plan for the development of rural tourism is simple, but for its implementation it is necessary to observe some obligations. To begin with, there should beinvestment in 
the form of fixed assets: land, houses suitable for receiving guests, transport, pets, vegetable garden or garden. Around or nearby should be located a picturesque area in the form of forests, meadows, natural reservoirs. A tourist should want to work, acquire new skills in work and life in the countryside. At the same time, guests will need to be taken care of as family members. There is a need of entertainment. This will help experience in organizing public holidays, knowledge of local traditions and rituals, mastery of crafts, stories about the history of the area, cultural features.

Rural tourism focuses not only on domestic, but also on foreign tourists. In this part, knowledge of a foreign language, national cuisines is necessary. Not everyone will agree on a daily "village" table.

A new promising area i.e. rural tourism initially does not require large financial investments. You can start with available resources, and then increase the volume. State registration of activities and compliance with all legal requirements is mandatory.

In the Chechen Republic, there is some experience in the development of tourism in small towns since the Soviet era. For example, a tourist base in the village of Benoy in the Vedeno district functioned successfully. The base was of All-Union significance and up to three thousand tourists passed through it in a season. Dozens of people were engaged in permanent work: instructors, drivers, technical and medical workers, cooks. From the hostel, hiking and horse riding routes ran to Lake Kezenoi Am, Makazhoy and further to the Soviet (Shatoi) districts.

In the Chechen Republic today there are 16 comfortable hotels, mostly private, with a total of one thousand beds. Two local tour operators offer 13 routes including a trip to waterfalls in the villages of Buni and Boskhoy.

To organize rural tourism in the Chechen Republic, it is necessary to develop an algorithm for the actions of participants in this process.

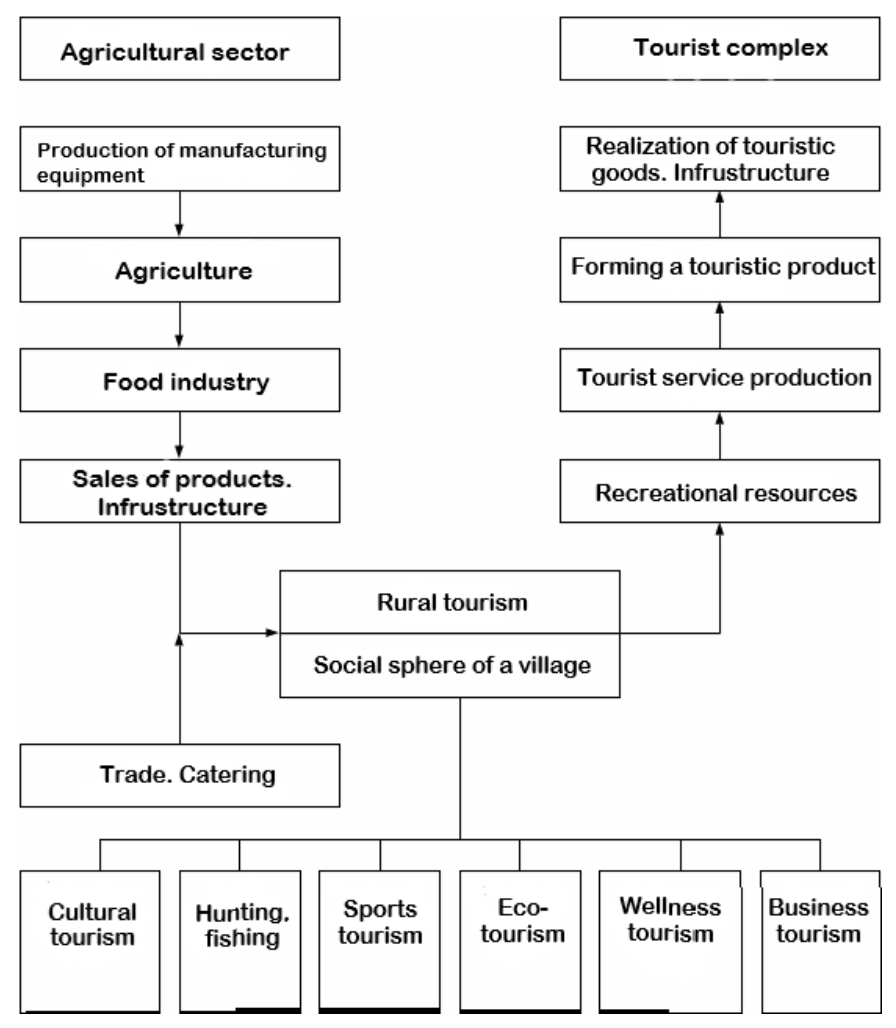

Rural tourism can get effective development in the spaces of villages; small cities with unique architecture, local life, culture; farms; forestland; natural complexes. For this, it is nec- 
essary to create an infrastructure with safe conditions for tourists to stay, while not violating the ecology of the surrounding nature.

The development of rural tourism, as a promising direction of the rural economy of the country, as the necessary conditions involves

- the presence of free or conditionally free housing in rural areas;

- good condition of this housing stock with a sufficient level of comfort;

- systemic state support for rural tourism: making a political decision to support rural tourism as a service sector;

- organizational support: the creation of special structures that provide systematic assistance and are involved in organizing this sector of the tourism industry, as well as the introduction of information technologies that allow creating a large-scale rural tourism market in virtual form;

- organization of associations of rural tourism entities supporting portals with databases for the entire agro-tourism sector;

- legal and regulatory (adoption of relevant laws and state programs), informational and advertising-informational support for the promotion of aggregate national and regional agrotourism products;

- financial support.

Pure rural tourism is not yet fully developed. There are a large number of factors that hinder the development of rural tourism in the Chechen Republic: this is the lack of information on tourist sites and routes in the Chechen Republic; there is no local interest in the development of rural tourism, and there is no regulatory framework.

The development of rural tourism will also contribute to the development of rural areas. Rural tourism factors contributing to the development of rural areas: the possibility of additional income for local residents; revival of folk crafts, cultural traditions; increased selfesteem of local residents, harmonization of society; creation of a favorable living environment, preservation of historical objects; infrastructure development, improvement of housing improvement.

Thus, it is necessary first to work with the population of the Chechen Republic to clarify the possibilities of rural tourism in the region. Here is a huge field for initiatives. Entrepreneurship in rural tourism has a multiplier effect, that is, one type of business becomes an initiative for another.

Rural tourism in the Chechen Republic can become a significant source of basic or additional income for the rural population.

\section{Лumepamypa}

1. Вахитова 3.Т. Развитие сельского туризма // Научно-исследовательские публикации. №14 (18). 2014. С. 10-15.

2. Дашкова Е.В., Ивушкина Е.Б. Музееведение / учебное пособие для вузов. Шахты: ЮРГУЭС, 2009.

3. Ивушкина Е.Б., Дашкова Е.В., Щербакова В.М. Межкультурная коммуникативная компетентность в подготовке специалистов индустрии туризма // Гуманитарные и социально-экономические науки. 2016. № 1 (86). С. 25-28.

4. Оценка численности населения по муниципальным районам и городским округам Чеченской Республики на 1 января 2020 года [Электронный ресурс]: официальный сайт Территориального органа Федеральной службы государственной статистики по Чеченской Республике. URL: https://chechenstat.gks.ru/folder/38713 (дата обращения 02.02.2020) 
1. Vakhitova Z.T. Razvitiye selskogo turizma. Nauchno-issledovatelskiye publikatsii. [The development of rural tourism. Research publications]. No. 14 (18). 2014. pp. 10-15 (In Russian).

2. Dashkova E.V., Ivushkina E.B. Muzeyevedeniye / uchebnoye posobiye dlya vuzov. [Museology / study guide for universities]. Shakhty: YURGUES. 2009. (In Russian).

3. Ivushkina E.B., Dashkova E.V., Shcherbakova V.M. Mezhkulturnaya kommunikativnaya kompetentnost $v$ podgotovke spetsialistov industrii turizma. Gumanitarnyye i sotsialnoekonomicheskiye nauki. [Intercultural communicative competence in the training of tourism industry specialists. Humanitarian and socio-economic sciences]. 2016. No. 1 (86). pp. 25-28 (In Russian).

4. Estimation of the population by municipal districts and urban districts of the Chechen Republic as of January 1, 2020. Official site of the Territorial Authority of the Federal State Statistics Service for the Chechen Republic.

Available at: https://chechenstat.gks.ru/folder/38713, (accessed: 2 February 2020). 